\title{
EVALUATION OF FAT PRODUCTION CONSUMPTION BY TRAINING AMATEURS
}

\author{
OCENA SPOŻYCIA PRODUKTÓW TŁUSZCZOWYCH \\ PRZEZ OSOBY TRENUJĄCE AMATORSKO
}

\begin{abstract}
Chair of Vascular and Internal Diseases, Department of Gastroenterological Nursing, Faculty of Health Sciences, Ludwik Rydygier Collegium Medicum in Bydgoszcz, Nicolaus Copernicus University in Toruń
\end{abstract}

Su m mary

Physical activity strengthens the musculoskeletal system, prevents commonly known problems such as backache and degenerative changes of the spine. Enhancing muscle strength reduces their load in daily activities. The increase of flexibility and agility along with balance decreases the risk of bone fractures and osteo-articular system [10]. One of the main causes of death in Poland are cardiovascular diseases. Physical activity is a relevant element of prevention of those diseases.

The main aim of this study was the evaluation of fats consumption in the diet of men training in FIT-MAX GYM club in Bydgoszcz. Additional aims were: determining motives for taking up and frequency of physical activity of the surveyed; the assessment of subjective evaluation of dieting and the knowledge of nutrition influence on the blood lipid profile.

Result analysis and necessary calculations were done with use of the program Microsoft Excel. Data necessary for the study were gathered in FIT-MAX GYM club in Bydgoszcz among adult men. Anonymous questionnaire including 25 questions about the history of nutrition was held.

Conclusions. 1. Men training at FIT-MAX GYM club in Bydgoszcz positively assessed their diet, especially when it comes to appropriate fat products consumption. 2. Physical activity was taken up by the respondents in order to improve their figure and mood. 3. Study group should be educated about the influence of dieting on blood lipid profile.

\section{Streszczenie}

Aktywność fizyczna wzmacnia układ ruchu, zapobiegając powszechnym problemom, takim jak bóle pleców i zmiany zwyrodnieniowe kręgosłupa. Wzmacnianie siły mięśni zmniejsza ich obciążenie podczas wykonywania czynności życia codziennego. Zwiększenie gibkości i zwinności, wraz ze zdolnością utrzymania równowagi, zmniejsza ryzyko złamań i innych urazów układu kostnostawowego [10]. Jedną z głównych przyczyn zgonów w Polsce są choroby układu krążenia. Aktywność fizyczna stanowi istotny element ich profilaktyki.

Głównym celem pracy była ocena spożycia produktów tłuszczowych w diecie przez mężczyzn ćwiczących w klubie FIT-MAX GYM w Bydgoszczy. Cele dodatkowe stanowiło: - zbadanie motywów, celu oraz częstotliwości podejmowania aktywności fizycznej przez badanych; - zbadanie subiektywnej oceny sposobu żywienia oraz wiedzy na temat wpływu żywienia na profil lipidowy krwi.

Analizę wyników oraz niezbędne obliczenia przeprowadzono za pomocą programu Microsoft Excel. Dane potrzebne do przeprowadzenia badania zebrano $\mathrm{w}$ klubie FIT-MAX GYM w Bydgoszczy, w grupie pełnoletnich mężczyzn. Badanie przeprowadzono anonimową ankietą z historią żywienia, zawierającą 25 pytań.

Wnioski. 1. Mężczyźni ćwiczący w klubie FIT-MAX GYM w Bydgoszczy dobrze ocenili swoją wiedzę i sposób żywienia, zwłaszcza w aspekcie spożycia odpowiednich produktów tłuszczowych. 2. Aktywność fizyczna była podejmowana przez badanych mężczyzn w celu poprawy sylwetki oraz poprawy samopoczucia. 3. Grupa badanych mężczyzn powinna być nadal edukowana w zakresie wpływu żywienia na profil lipidowy krwi.

Key words: physical activity, diet, fats consumption

Słowa kluczowe: aktywność fizyczna, żywienie, produkty tłuszczowe 
Fat is a term which describes both a nutrient substance and a food product group classified as visible fats [1]. Fat as a nutrient substance accounts for over a half of a daily consumed energy which, next to carbohydrates, is the main source of energy in human diet. Demand for fats varies from 15 to $30 \%$. Nutrition norms advise matching fat consumption to energy demand with regards to physiological state, body mass, age, gender and physical activity. For infants, fats provide $50 \%$ of consumed energy, from $6^{\text {th }}$ to $12^{\text {th }}$ month $40 \%$, for children aged 1 to 3 fats provide 30 $35 \%$ of basic energy supply. Fat share in the diet should decrease with age finally reaching 15-30\% (according to FAO/WHO) or 20-35\% (according to EFSA) in adult age [1,2,3]. From technological point of view, fats fulfil significant roles concerning food consumption. They lubricate the food which makes it easy to swallow and contribute to its tenderness. In melted fat, due to the higher temperature of treatment, other food products can be heated or fried giving them specific organoleptic characteristics [4]. Fats contain two times more energy than carbohydrates per one gram of product $(9 \mathrm{kcal}$ out of $1 \mathrm{~g}$ of fat to $4 \mathrm{kcal}$ out of $1 \mathrm{~g}$ of carbohydrates). Fat accumulated in the subcutaneous and visceral tissue is the main source of energy reserves for the body. The amount of fat gathered as reserves is unlimited, for people with the right body weight it represents $10 \%-15 \%$ of body weight for men and 15-25\% of body weight for women which corresponds with $5 \mathrm{~kg}$ to $20 \mathrm{~kg}$ of triglycerides gathered in spare adipose tissue. Average healthy human has $12 \mathrm{~kg}$ of spare adipose tissue which represents $110,000 \mathrm{kcal}$ of energy ensuring survival for 3 months without food [1, 2]. Dietary fats are a mix of different triglycerides. Simple glycerides are the main ingredient of the body fat reserve. Complex glycerides such as cholesterol, phospholipids and glycolipids are also a part of the organ adipose tissue [1]. Food fats consist of fatty acids with different saturation (saturated, poly- and mono-unsaturated) made of 4 to 26 carbon atoms. Depending on a carbon chain length, short-chain fatty acids (SCFA), medium-chain triglycerides (MCT) and long-chain triglycerides (LCT) can be distinguished.

\section{THE INFLUENCE OF FATTY ACIDS CONSUMPTION ON HUMAN HEALTH}

Fatty acids, due to their different chemical structure, influence human body differently. They play an essential role in regulating immune system and inflammatory substances. It is mainly attributed to n-6 and n-3 unsaturated long-chain fatty acids. The effect of n-3 acids was thoroughly described and tested in animal and human research which indicated significant, depending on the dose, anti-inflammatory effect by influencing key mediators. N-6 fatty acids were tested for making and triggering post inflammatory reactions with positive result. Key part of fatty acids effect on human body is their influence on metabolism and homeostasis. Fatty acids with trans geometric isometry present negative impact on lipid profile of human plasma increasing LDL level, decreasing HDL concentration and increasing triglycerides concentration in blood [5]. Significant increase of postprandial lipemia is caused by saturated long-chain fatty acids but not by MTC acids. Trans fatty acids cause similar action to acids with Cis-trans isomerism. They decrease lipemia on an empty stomach in comparison to high carbohydrate diet. There is evidence indicating significant influence of long term increased concentration of triglycerides on the risk of development of atherosclerosis and coronary heart disease [5]. The effect of n-3 poly-unsaturated fatty acids supplementation, over $3 \mathrm{~g}$ per day, on cytokines production decrease was presented, which can reduce inflammations and the risk of cardiovascular diseases. It is difficult to unequivocally demonstrate the influence of fatty acids consumption proportion in dietary programs having regard to a range of changing dietary factors. The influence of n-3 fatty acid consumption on blood pressure drop was confirmed [5].

\section{THE IMPORTANCE OF FAT CONSUMPTION FOR PHYSICAL ACTIVITY}

Fat is the second main source of energy for the working muscles. Fat used in muscles comes from four sources. Firstly, free fatty acids of plasma (FFA) are the main source of energy for physical activity with the intensity close to $50 \%$ of VO2max. After finishing physical activity, the concentration of free fatty acids in plasma and the speed of lipolysis quickly come back to their starting levels. Second energy source for skeletal muscles are muscle triglycerides which are the intramuscular reserve. Their lipolysis is activated by the adrenaline. The highest usage of those muscles, estimated to be $25 \%$ of energy use, occurs for physical activity with the intensity close to $65 \mathrm{VO} 2 \mathrm{max}$. As 
a result of an increase in lipoprotein lipase activity in muscles and its decrease in adipose tissue, triglycerides utilization in plasma decreases. Triglycerides are the third source of energy, supplying $5 \%$ of energy to the muscles. The last source of energy are ketone compounds, oxidation of which is possible in skeletal muscles. They are not a significant substrate for people on a high carbohydrate diet [6]. The ability to utilize fats as a source of energy during physical activity grows with their consumption growth, however, longterm effect of increased consumption of fats on physical performance is not yet determined. [2]. Nutritional demand of fats is the same for people who are physically active and for those who are not. It should cover $30 \%$ of daily energy intake. A lot of attention is paid to insufficient n-3 poly-unsaturated fatty acids consumption with over-consumption of $n-6$ acids. $\Omega-3$ acids have many benefits helping physical activity. They strengthen post-workout muscle tissue recuperation, water cell membranes, support nervous system and limit the production of pro inflammatory factors [7]. Sportsmen and physically active people look for effective strategies enabling effective body mass control. Despite the fact that limitation of fat consumption enables the amount of energy intake, carbohydrates consumption restriction allows the highest reduction of blood insulin levels. Low-fat diets increase the risk of decrease in the sexual hormones concentration, insufficient consumption of fat soluble vitamins $(\mathrm{A}, \mathrm{D}, \mathrm{E}, \mathrm{K})$ and necessary unsaturated fatty acids [7].

\section{EFFECT OF PHYSICAL ACTIVITY ON HUMAN HEALTH}

Physical activity strengthens the musculoskeletal system, prevents commonly known problems such as backache and degenerative changes of the spine. Enhancing muscle strength reduces their load in daily activities. The increase of flexibility and agility along with balance decreases the risk of bone fractures and osteo-articular system [6]. One of the main causes of death in Poland are cardiovascular diseases. Physical activity is a relevant element of prevention of those diseases. Numerous studies indicate lower incidence of ischemic heart disease and lower risk of myocardial infarction in people who are physically active than for those with sedentary lifestyle. Low physical activity is one of risk factors of ischemic heart disease along with hypertension, dyslipidemia, glucose intolerance and diabetes, obesity and smoking [6]. Hypertension which afflicts $20 \%$ of population, despite genetic component, is subjected to complex control mechanisms concerning physical activity. Insulin also aids hypertension, production of which reduces in reaction to physical exercise. Lipid disorders also reduce. Physical activity lowers plasma triglycerides levels, overall cholesterol, VLDL and LDL lipoproteins. HDL concentration rises in reaction to physical activity which is a significant protective factor. The increase in lipoprotein lipase enzyme activity and tissue insulin sensitivity is observed. Glucose intolerance, which can consequently lead to type 2 diabetes, is also regulated as a result of increased glucose uptake into cells and insulin sensitivity. The amount of GLUT-4 glucose transporters in muscle fibres increases with their relocation towards cell membranes [6]. Physical activity is vital in obesity prevention and treatment. It has been shown that physically active people are less subjected to the problem of excessive weight and beneficial influence of physical activity in body mass reduction, body fat reduction and an increase in lean body mass were proven in intervention studies [8]. Physical activity undertaken in early adult life may have a beneficial impact on the quality of life in old age.

\section{AIM OF THE STUDY}

The main aim of this study was the evaluation of fats consumption in the diet of men training in FITMAX GYM in Bydgoszcz. Additional aims were: determining motives for taking up and frequency of physical activity of the surveyed; the assessment of subjective evaluation of dieting and the knowledge of nutrition influence on the blood lipid profile.

\section{MATERIAL AND METHODS}

Methodology of result analysis and dietary intake

Result analysis and necessary calculations were done with use of the program Microsoft Excel. Data necessary for the study were gathered in FIT-MAX GYM in Bydgoszcz among adult men. Anonymous questionnaire including 25 questions about the history of nutrition was carried out. Introduction to this questionnaire had information about anonymity and the aim of the study. There was also a paragraph about the definition of fat product as food product along with examples. The first part, containing 9 questions, 
6 closed questions and 3 opened questions, involved anthropometric measurements, body mass, height and socio-demographic status such as age, education, residence and occupation. The second part contained 8 questions involving physical activity and the assessment of subjective evaluation of dieting of the surveyed. It contained questions about the frequency of physical activity during the week, type and aims and an average time of a single training session. There was also a question about the knowledge of healthy nutrition, its application, dieting and subjective evaluation of the diet of the surveyed. Third part contained a table of the consumption frequency of selected fat products in the scale from daily consumption to occasional consumption during the year. Surveyed also answered also about 7 questions concerning the motives for fat products consumption, subjective opinion about edible fat influence on human life and achieving goals connected with taking up physical activity. Respondents also listed products which in their opinion are the best for human health. Surveyed were asked about their knowledge of fat product influence and fatty acids in them on blood cholesterol level and blood control tests in order to asses cholesterol level.

\section{RESULT AND CONCLUSIONS}

Characteristics of the surveyed group. 100 adult men training at FIT-MAX GYM club in Bydgoszcz were surveyed. Due to incomplete information, data obtained from 16 respondents was excluded from the analysis and it limited the number of surveyed group to 84. The approval of Bioethical Commission of Mikołaj Kopernik University in Toruń Ludwik Rydygier Collegium Medicum in Bydgoszcz. All people taking part in the study were informed about the purpose and anonymity of the study. It was carried out from April to May 2014. Average age was 27.48 years old ( $\mathrm{SD}=7.82$; range $18-56$ years old). Anthropometric characteristics in table 1 .

Tab. 1. Anthropometric characteristics of the study group

\begin{tabular}{|l|c|c|c|c|}
\hline Feature & $\min$ & $\max$ & mean & SD \\
\hline Height & 165 & 196 & 180.7 & 7.24 \\
\hline $\begin{array}{l}\text { Body } \\
\text { mass(kg) }\end{array}$ & 58 & 108 & 86.2 & 12.14 \\
\hline BMI & 19.3 & 23.9 & 26.2 & 2.94 \\
\hline
\end{tabular}

A vast majority of the respondents $(75 \%) \%)$ were living in the city with population from 100,000 to
500,000. The largest share in the study group were people with secondary and higher education in comparison to people with vocational and lower secondary education. Most men were single (69\%) with the rest married or living in informal relationships. $50 \%$ of respondents were still in the course of education and 60 people (71.4\%) were working. 24 men $(28.6 \%)$ were unemployed. 23 of working men $(38.3 \%)$ carried out mental work and 9 of them were working physically. 28 of respondents $(33.3 \%)$ had a mixed type of work.

\section{PHYSICAL ACTIVITY OF THE RESPONDENTS}

Most of the surveyed men (55 people $-65 \%$ ) took up more than one type of physical activity, on the other hand, 81 of the respondents declared performing strength exercises. 42 respondents $(50 \%)$ performed cardio training; 1 men attended fitness training with the female instructor; 21 of the respondents (25\%) declared participation in martial arts training lead by instructors, 14 men took up various forms of physical activity not included in the club offer.

Respondents took up physical activity with different frequency during the week, 46 of respondents $(54.8 \%)$ attended training 4-5 times a week. 28 of respondents $(33.3 \%)$ declared their attendance 2-3 times a week; 7 men (8.3\%) exercised 6-7 times a week; physical activity was taken up 1-2 times a week by 2 respondents; only one men (1.2\%) declared training more than 7 days a week.

Tab. 2. Reasons for taking up physical activity

\begin{tabular}{|l|c|c|}
\hline \multirow{2}{*}{ Target physical activity } & \multicolumn{2}{|c|}{ Number of subjects } \\
\cline { 2 - 3 } & $\mathrm{n} \%$ & $\mathrm{n}$ \\
\hline Muscular mass building & 73.8 & 62 \\
\hline Mood improvement & 66.7 & 56 \\
\hline Endurance improvement & 39.3 & 33 \\
\hline $\begin{array}{l}\text { Aerobic performance } \\
\text { improvement }\end{array}$ & 25.0 & 21 \\
\hline Body weight loss & 29.8 & 25 \\
\hline Increase muscle strength & 8.3 & 7 \\
\hline Other goals & 3.6 & 3 \\
\hline Loss of fat tissue & 1.2 & 1 \\
\hline Efficiency improvement & 1.2 & 1 \\
\hline Stress reduction & 1.2 & 1 \\
\hline Body improvement & 1.2 & 1 \\
\hline
\end{tabular}

Average time of a single training session in FITMAX GYM club in Bydgoszcz was 1.5 hours. Men declared following reasons for taking up physical activity: muscular mass building (62 people, $73.8 \%$ ); mood improvement (56 of men, 66.7\%); endurance improvement (33 of respondents,39.3\%); aerobic 
performance improvement (21 of respondents, $25 \%$ ); body weight loss (25 of respondents, 29.8\%). Other goals not included in questionnaire were declared by 7 respondents $(8.3 \%)$

\section{RESPONDENTS' NUTRITION SELF-ASSESSMENT}

Respondents during the survey made subjective evaluation of their knowledge of proper nutrition. Among all respondents, 64 people $-76.2 \%$, declared their knowledge of proper nutrition rules; 7 people $(8.3 \%)$ declared their lack of knowledge of proper nutrition rules; 13 (15.5\%) people had no opinion. Application of the rules of proper nutrition was declared by 58 respondents (69\%); 26 respondents (31\%) did not apply the rules of proper nutrition. 27 surveyed men $(32.1 \%$ ) applied a diet; 57 men (67.9\%) responded negatively to the question about the diet application. Men using a diet declared various forms of nutrition, manipulating consumption of specified macroelements or diets influencing body composition. Most of the respondents applied high-protein diet (11 people, $13.1 \%$ ).

In the course of the study, respondents subjectively evaluated their own diet. 66 respondents (78.6\%) provided positive assessment of their diet; 18 men $(21.4 \%)$ described their diet as bad.

\section{FAT PRODUCTS CONSUMPTION IN THE STUDY GROUP}

From among animal fats, butter was consumed most frequently. Milk fat was chosen daily by 15 respondents $(17.9 \%)$; 6-5 times a week by 7 respondents $(8.3 \%) ; 5$-4times a week by 4 respondents (4.8\%); 3-2 times a week by 13 respondents $(15.5 \%)$; once a week by 13 respondents (15\%). Butter was never consumed by 16 respondents (19\%). Surveyed consumed lard and salo far less frequently. Lard was consumed few times a year by 29 respondents $(34.5 \%)$ and not consumed at all by 51 respondents $(60.7 \%)$. Salo was consumed by 13 respondents (15.5\%) few times a year. It was not consumed by 70 respondents $(83.3 \%)$. Soft margarine consumption was slightly higher than hard margarine. 5 respondents $(6 \%)$ consumed soft margarine daily and 2 people $(2.4 \%)$ consumed hard margarine every day. Occasional consumption was more frequent for hard margarine, consumed few times a month by 9 respondents
(10.7\%), and consumed few times a year by 12 respondents (14.3\%). Most frequently consumed vegetable oil was olive oil, rapeseed oil and sunflower oil. Daily consumption was the highest for olive oil -7 respondents $(8.3 \%)$, rapeseed oil and sunflower oil consumption was respectively $2.4 \%$ ( 2 respondents) and $1.4 \%$ ( 1 respondent) of all surveyed people. Rapeseed oil and sunflower oil consumption was more frequent than olive oil when it comes to occasional use. Rapeseed oil was consumed few times a month by 19 respondents $(22.6 \%)$, sunflower oil by 20 respondents $(23.8 \%)$ Frequent daily consumption of linseed oil was observed for $7.1 \%$ of surveyed (6 respondents). The least consumed oil from oils of vegetable origin were coconut oil, soybean oil and walnut oil. Coconut oil was not consumed by the majority of respondents (69 people, $82 \%$ ), soybean oil by 71 respondents $(84.5 \%)$. Walnut oil was consumed few times by only 10 respondents $(11.9 \%)$ and 62 respondents $(73.8 \%) \mathrm{did}$ not use that product.

Main factor determining the choice of fat products by the respondents was a conviction about their health effects (43 respondents, 51.2\%). The result on the figure was a factor for 17 respondents $(20.2 \%)$; the influence on sport's results was the factor for choosing fat products for 5 respondents $(6 \%) ; 4$ respondents $(4.8 \%)$ indicated their well-being as a decisive factor; one respondent listed taste as a main factor; 14 people (16.7\%) had no opinion.

Tab. 3. Main factor determining the choice of fat products

\begin{tabular}{|l|c|c|}
\hline \multirow{2}{*}{$\begin{array}{l}\text { Factor determining the } \\
\text { choice of fat products }\end{array}$} & $\mathrm{n} \%$ & $\mathrm{n}$ \\
\cline { 2 - 3 } & 51.2 & 49 \\
\hline Health effects & 4.8 & 4 \\
\hline Well-being & 20.2 & 17 \\
\hline The result on the figure & 6 & 5 \\
\hline $\begin{array}{l}\text { The influence on sport's } \\
\text { results }\end{array}$ & 16.7 & 14 \\
\hline No opinion & 1.2 & 1 \\
\hline Other goals & 1.2 & 1 \\
\hline Taste attributes & & \\
\hline
\end{tabular}

43 respondents $(51.2 \%)$ considered fat products beneficial to health; 15 respondents $(17.9 \%)$ did not consider fat products beneficial to health. 26 respondents $(30.1 \%)$ had no opinion. The surveyed who responded positively to the question concerning health-improving effect of fat products (43 men) were asked to name three of them that they found the most healthy. The first most frequently specified product was olive oil, second was linseed oil and third was walnut oil. Another products specified by respondents were rapeseed oil and sunflower oil. Percentages 
responding to 43 surveyed who responded positively to the question concerning health-improving effect of fat product are in Table 4.

Tab. 4.

\begin{tabular}{|l|c|c|}
\hline \multirow{2}{*}{ Fat product } & \multicolumn{2}{|c|}{ Number of subjects } \\
\cline { 2 - 3 } & $\mathrm{n} \%$ & $\mathrm{n}$ \\
\hline olive oil & 93.0 & 40 \\
\hline linseed oil & 72.1 & 31 \\
\hline walnut oil & 34.9 & 15 \\
\hline rapeseed oil & 30.2 & 13 \\
\hline sunflower oil & 16.3 & 7 \\
\hline
\end{tabular}

From among the surveyed, 40 men (47.6\%) claimed that consuming fat products beneficially influenced their well-being. 13 respondents (15.5\%) responded negatively to that question; 31 respondents $(36.9 \%)$ had no opinion.

\section{RESPONDENTS' KNOWLEDGE ABOUT CHOLESTEROL}

Surveyed were also asked about their views on positive influence of fat products consumption on achieving goals connected with taking up physical activity. 44 respondents $(52.4 \%)$ gave positive answer; 17 respondents $(20.2 \%)$ did not believe that fat products consumption helped them with achieving goals connected with taking up physical activity; 23 men $(27.4 \%)$ had no opinion. Respondents in the vast majority (67 men, 79.8\%) did not test their blood cholesterol level, 17 people tested their blood cholesterol level regularly. 29 people $(34.5 \%)$ had knowledge of fat product consumption influence on cholesterol level. 55 respondents had no opinion $(65.5 \%)$

\section{DISCUSSION}

Over the last few decades obesity has become a serious health and social problem affecting all people regardless of their age, race or gender. This problem also concerns Polish population. Obesity is connected with many complications, it is a factor causing cardiovascular diseases, type 2 diabetes, cancer and digestive diseases. It increases mortality rates, shortens the period of life, causes the increase in the outlays for the Health Service, macroeconomic losses and detriment to quality of life $[9,10]$. Obesity and insulin dependent diabetes were the main cause of hospitalisation in 2008 in Poland [11]. Appropriate selection of food products and training are the elements of prevention of obesity and accompanying illness $[1,9,12]$. Numerous epidemic studies have shown physical activity to be beneficial to human health, not only reducing body mass but also improving cardiovascular system, muscles, osteo-articular system, respiratory system as well as glucose metabolism and the blood lipid profile. Regular physical activity allows maintaining good mental health [9,13]. Taking up physical activity at a young age positively influences the quality of life in old age [14]. There are not many reports concerning nutrition method and food product selection for men training at fitness clubs. This makes comparative discussion virtually impossible due to the nature of asked questions. Author's study enabled gathering data concerning dieting of physically active men. Over the decades, due to an easy access to training facilities and the low cost, strength training has gained popularity. On the other hand, the stereotyped view of people attending gyms has been negative those people are thought to be only concerned with their figure and not health. The subject matter for strength training has appeared in scientific publications mostly in relation to substances used in doping and supplementation with its effects [15]. Because of that, the aim of this study was to discuss the matter of nutrition and the knowledge of it along with the health effects among men training at FIT-MAX GYM club in Bydgoszcz. Data gathered in this study concerning respondents' BMI was on average 26.2. This result is similar to the one in the study by Adamczyk and et al. carried out within a group of men attending gyms in Warsaw. Authors noted average BMI 25.02 for men training less than 3 years and 27.2 for men training longer than 3 years. In accordance with the interpretation of BMI it may indicate overweight but BMI should not be used to calculate body mass for people who are physically active and have more than average muscular mass [7]. Most of men performed strength training. Resistance training, apart from benefits of diseases of civilization prevention, is vital for increasing bone density and bone fractures prophylaxis as well as maintaining proper body mass and muscular strength [13]. Taking up various exercises is the most beneficial for health improvement and disease prevention. Cardio exercises taken up by $50 \%$ of respondents offer better benefits than resistance training concerning respiratory system, cardiovascular system and also carbohydrate and lipid metabolism $[5,13]$. Most of the respondents took up physical activity with the frequency suitable for the age group 
between 18-64 years old, set by WHO as 2 or more training sessions a week, including main muscle groups, which corresponds with 150 minutes of moderate exercises or 75 minutes of intensive exercises [12]. Primary motives for taking up physical activity at FIT-MAX GYM club in Bydgoszcz was the increase of muscular mass and mood improvement (respectively $73.8 \%$ and $66.7 \%$ of respondents). This result was similar with the study by Adamczyk and colleagues which showed that the main reason for training was mood and figure improvement. The increase of muscular mass was not listed among the motives for men training in Warsaw but it was the reason for taking dietary supplements. $92 \%$ of men training more than 3 years admitted to taking supplements the same as $64 \%$ of men training less than 3 years. In the author's study only $3.6 \%$ of respondents listed the increase of muscular strength as their training goal. This result was different from the one obtained in the study by Adamczyk et al. which showed that $59 \%$ of respondents aimed at that parameter improvement. This difference may be due to respondents' involvement in strength sports such as power lifting and weightlifting [15]. Among male respondents, $32.1 \%$ declared implementing diet and nutrition modification. 11 of them were on protein rich diet. High protein intake as a significant macro element in a sportsmen nutrition benefits long term body composition, supports muscle protein synthesis, intensifies burning body fat and the sense of satiety. Furthermore, protein consumption allows lower energy intake and keeps appropriate body mass [16, 17]. Replacing carbohydrates with protein in the diet benefits blood lipid profile, decreasing low density triglycerides and lipoprotein concentration. Clinical studies indicate that high protein diet along with strength training increases slimming effectiveness, allows higher body mass loss, improves glycemic control and cardiovascular risk markers control [18]. The studies concerning resistance training have shown that enriching diet with protein nutrients containing whey protein is beneficial for treating obesity and increases lean body mass growth [19]. Moreover, it has been proven that consuming meals rich in protein controls the appetite [20]. In connection with the popularity of diets rich in protein as a method of weight loss, attention is drawn to their negative influence of kidney function. There is evidence that protein consumption should be minimized for people suffering from kidney diseases, however, there are not enough scientific studies to prove that increased protein consumption causes the risk of those diseases. It may seem that perfectly functioning body adjusts organ functioning to increased consumption of that element [21]. In own study, 2 respondents declared low carbohydrate diet. Low carbohydrate diet is a nutrition method which reduces carbohydrate demand to 30$150 \mathrm{~g}$ a day. Clinical studies have shown effectiveness of carbohydrate restriction in treating obesity, positive impact of this diet on insulin resistance indexes and blood glucose control for both healthy people and people with type 2 diabetes. Low carbohydrate diet controls appetite and blood lipid profile by increasing high density lipoprotein concentration in blood [22]. Low carbohydrate diet have been seen as a threat to health for a long time. However, clinical studies have proven the advantage of those diets over low fat diets in obesity and metabolic diseases treatment [23]. Data analysis in this study concerning the frequency of products of animal origin consumption showed that butter was frequently used in a daily diet. Butter, due to high content of saturated fatty acids and cholesterol, has been considered as a product causing atherosclerosis [24]. According to the latest research including both observational and clinical studies, saturated fatty acids are not a risk factor for cardiovascular diseases $[25,26]$. Consumption of dairy products with high level of fat is connected with better body composition despite high energy supply. Prospective research concerning full fat dairy products has shown reversely proportional relation between butter consumption and percentage of body fat within the study group. Consumption of those products was not correlated with the risk of cardio-metabolic diseases [28]. Biologically active components of milk fat such as conjugated linoleic acid (CLA) may have a positive effect in that area [27,28]. Hard margarine consumption, created by the hydrogenation of unsaturated fats, has adverse effects on circulatory diseases occurrence. During this process trans geometric isomers are created, which is the risk factor for atherosclerosis [27]. It is suggested that trans fatty acids should be replaced with other fatty acids due to their harmful effect on lipid concentration and structure, and plasma lipoproteins [29]. In this study positive view and frequent consumption of olive oil was observed, which has a positive influence on people's health. Olive oil and monounsaturated fatty acids in it are seen as one of the healthiest nutrients. When designing a healthy diet, implementing 
monounsaturated fatty acids with protein instead of carbohydrates can improve plasma lipid levels, decrease body mass, blood pressure which in turn will lead to cardiovascular risk decline [30]. Olive oil is one of the ingredient of Mediterranean diet seen as one of the healthiest nutrition model. This is also confirmed in scientific literature and this kind of diet can lower type 2 diabetes development risk [31]. Clinical study has shown positive influence of a diet rich in olive oil in cardiovascular diseases prevention [32]. Consumption of olive oil is associated with the lower risk of cancer of any kind [33]. This study also included linseed oil in respondents' diet, which similarly to olive oil is perceived as a healthy product. Linseed oil consumption, rich in n-3 fatty acids $-\omega$ linoleic acid, increases concentration of eicosapentaenoic acid (EPA) with cardio-protective nature [34]. Beneficial influence of linseed oil is observed. It decreases cholesterol and lipoprotein (LDL) concentration [35]. In this study only 17 respondents $(20,2 \%)$ tested their blood lipid concentration regularly. It may indicate insufficient knowledge of threats connected with abnormal blood lipid profile and the need for education of the study group about that matter. As Polish experts indicate in Sopot Declaration, insufficient diagnostic of lipid disorders is the current problem in Poland. Lipid disorders are one of the main heart diseases risk factors, they appear to be a modifiable factor though. This problem concerns adults, children and teenagers. Everyone over the age of 20 should be subjected to preventive testing of cholesterol level. It could ensure early detection and treatment of hypercholesterolemia and dyslipidemia and consequently the drop in mortality rates due to cardiovascular diseases [36].

\section{CONCLUSION}

Men training at FIT-MAX GYM club in Bydgoszcz positively assessed their diet, especially when it comes to appropriate fat products consumption. 2. Physical activity was taken up by the respondents in order to improve their figure and mood. 3. Study group should be educated about the influence of dieting on blood lipid profile.

\section{REFERENCES}

1. Ciborowska H., Rudnicka A., Składniki odżywcze i ich znaczenie w żywieniu, Normy żywienia i wyżywienia, Dietetyka. Żywienie zdrowego i chorego człowieka, Red.
Woińska E., Wydawnictwo Lekarskie PZWL, Warszawa 2009, 65-93, 187-190.

2. Konturek S. J., Trawienie i wchłanianie tłuszczów, Fizjologia człowieka. Podręcznik dla studentów medycyny, Red. Konturek S. J., Elsevier Urban \& Partner, Wrocław 2007, 556-559.

3. Szponar L., Mojska H., Ołtarzewski M., Tłuszcze, Normy żywienia dla populacji polskiej - nowelizacja, Red. Jarosz M., Instytut Żywności i Żywienia, Warszawa 2012, 44-48

4. Pijanowski E., Dłużewski M., Dłużewska A., Jarczyk A., Podział produktów spożywczych, Ogólna technologia żywności, Red. Wiśniewska M., Wydawnictwa Naukowo-Techniczne, Warszawa 2004, 81-82.

5. Summary of conclusions and dietary recommendations on total fat and fatty acids, Fat and fatty acid requirements for adults, Fat and fatty acid intake and inflammatory and immune response, Total fat, fatty acid intake and cancers, Fat and fatty acid intake and metabolic effects in the human body, Dietary fat and coronary heart disease, Fat intake and CNS functioning: ageing and disease, Fat and fatty acids in human nutrition, Food and Agriculture Organization of the United Nations, Rzym 2010, 9-20, 55-62, 91-138.

6. Górski J., Nazar K., Kaciuba-Uściłko H., Metabolizm substratów energetycznych, Znaczenie aktywności ruchowej w zapobieganiu chorobom cywilizacyjnym, Fizjologiczne podstawy wysiłku fizycznego, Red. Górski J., Wydawnictwo Lekarskie PZWL, Warszawa 2008, 456-459, 546-556

7. Lowery L. M., Dietary Fat and Sports Nutrition: A Primer, J Sports Sci Med. 2004; 3 (3) 106-117.

8. Plewa M., Markiewicz A., Aktywność fizyczna w profilaktyce i leczeniu otyłości, Endokr, Otyłość i Zab Przem Mat 2006; 1 (2) 30-37.

9. Kłosiewicz-Latoszek L., Otyłość jako problem społeczny, zdrowotny i leczniczy, Probl Hig Epidemiol 2010; 91 (3) 339-343.

10. Zapolska J., Zarębska A., Ostrowska L., Fitness w leczeniu nadwagi i otyłości, Forum Zab Metabol. 2010; 1 (2) 100-105.

11. Gajewska M., Goryński P., Wysocki M. J., Otyłość i cukrzyca typu 2 jako główne przyczyny hospitalizacji w polskich szpitalach w 2008 roku, Probl Hig Epidemiol 2011; 92 (1) 132-136.

12. Recommended population levels of physical activity for health, Global recommendations on physical activity for health, World Health Organization, Geneva 2010, 15-34.

13. Kopff B., Aktywność fizyczna w profilaktyce chorób cywilizacyjnych, Choroby społeczne i cywilizacyjne wybrane zagadnienia, Red. Bąk-Romaniszyn L., Uniwersytet Medyczny w Łodzi, Łódź 2013, 7-24.

14. Grochowska A., Kołpa M., Musiał Z., Wpływ otyłości na funkcjonowanie osób dorosłych, Probl Pieleg. 2010; 1 (1) 25-29.

15. Adamczyk J. G., Kowalski P., Boguszewski D., Ochal A., Siewierski M., Postawy prozdrowotne u mężczyzn regularnie ćwiczących na siłowni, Pedagog. psihol. med.biol. probl. fiz. vihov. sportu 2012; 2, 138-145. 
16. Paddon-Jones D., Westman E., Mattes R. D., Wolfe R. R., Astrup A., Westerterp-Plantenga M., Protein, weight management, and satiety, Am J Clin Nutr. 2008; 87 (5) 1558-1561.

17. Halton T. L., Hu F. B., The effects of high protein diets on thermogenesis, satiety and weight loss: a critical review, J Am Coll Nutr. 2004; 23 (5) 373-385.

18. Wycherley T. P., Noakes M., Clifton P. M., Cleanthous X., Keogh J. B., Brinkworth G. D., A high - protein diet with resistance exercise training improves weight loss and body composition in overweight and obese patients with type 2 diabetes, Diabetes Care. 2010; 33 (5) 969976.

19. Miller P. E., Alexander D. D., Perez V., Effects of whey protein and resistance exercise on body composition: a meta - analysis of randomized controlled trials, J Am Coll Nutr. 2014; 33 (2) 163-175.

20. Leidy H. J., Armstrong C. L., Tang M., Mattes R. D., Campbell W. W., The influence of higher protein intake and greater eating frequency on appetite control in overweight and obese men, Obesity (Silver Spring) 2010; 18 (9) 1725-1732.

21. Martin W. F., Armstrong L. E., Rodriguez N. R., Dietary protein intake and renal function, Nutr Metab (Lond). 2005; $2: 25$.

22. Westman E. C., Feinman R. D., Mavropoulos J. C., Vernon M. C., Volek J. S., Wortman J. A., Yancy W. S., Phinney S. D., Low - carbohydrate nutrition and metabolism, Am J Clin Nutr. 2007; 86 (2) 276-284.

23. Hite A. H., Berkowitz V. G., Berkowitz K., Low carbohydrate diet review: shifting the paradigm, Nutr Clin Pract. 2011; 26 (3) 300-308.

24. Cichosz G., Aterogenne właściwości tłuszczu mlekowego - rzeczywistość czy mit?, Prz. Lek. 2007; 64 (4) $32-34$

25. Siri-Tarino P. W., Sun Q., Hu F. B., Krauss R. M., Metaanalysis of prospective cohort studies evaluating the association of saturated fat with cardiovascular disease, Am J Clin Nutr. 2010; 91 (3) 535-546.

26. Hoenselaar R., Saturated fat and cardiovascular disease: the discrepancy between the scientific literature and dietary advice, Nutrition 2012; 28 (2) 118-123.

27. Cichosz G., Zdrowotne skutki substytucji thuszczu mlekowego olejami roślinnymi, Przegląd Mleczarski 2007; 12, 4-9.

28. Kratz M., Baars T., Guyenet S., The relationship between high - fat dairy consumption and obesity, cardiovascular, and metabolic disease, Eur J Nutr. 2013; 52 (1) 1-24.

29. Hunter J. E., Zhang J., Kris-Etherton P. M., Cardiovascular disease risk of dietary stearic acid compared with trans, other saturated, and unsaturated fattyacids: a systematic review, Am J Clin Nutr. 2010; 91 (1) 46-63.

30. Appel L. J., Sacks F. M., Carey V. J., Obarzanek E., Swain J. F., Miller E. R. 3rd, Conlin P. R., Erlinger T. P., Rosner B. A., Laranjo N. M., Charleston J., McCarron P., Bishop L. M., OmniHeart Collaborative Research Group, Effects of protein, monounsaturated fat, and carbohydrate intake on blood pressure and serum lipids: results of the
OmniHeart randomized trial, JAMA 2005; 294 (19) 2455-2464.

31. Salas-Salvado J., Bullo M., Babio N., Martinez-Gonzalez M. A., Ibarrola-Jurado N., Basora J., Estruch R., Covas M. I., Corella D., Aros F., Ruiz-Gutierrez V., Ros E., Reduction in the incidence of type 2 diabetes with the Mediterranean diet: results of the PREDIMED-Reus nutrition intervention randomized trial, Diabetes Care 2011; 34 (1) 14-19.

32. Estruch R., Ros E., Salas-Salvado J., Covas M. I., Corella D., Aros F., Gomez-Gracia E., Ruiz-Gutierrez V., Fiol M., Lapetra J., Lamuela-Raventos R. M., Serra-Majem L., Pinto X., Basora J., Munoz M. A., Sorli J. V., Martinez J. A., Martinez-Gonzalez M. A., Primary prevention of cardiovascular disease with a Mediterranean diet, N Engl J Med. 2013; 368 (14) 1279-1290.

33. Psaltopoulou T., Kosti R. I., Haidopoulos D., Dimopoulos M., Panagiotakos D. B., Olive oil intake is inversely related to cancer prevalence: a systematic review and a meta-analysis of 13,800 patients and 23,340 controls in 19 observational studies, Lipids Health Dis. 2011; $10: 127$.

34. Harper C. R., Edwards M. J., DeFilippis A. P., Jacobson T. A., Flaxseed oil increases the plasma concentrations of cardioprotective (n - 3) fatty acids in humans, J Nutr. 2006; 136 (1) 83-87.

35. Pan A., Yu D., Demark-Wahnefried W., Franco O. H., Lin X., Meta - analysis of the effects of flaxseed interventions on blood lipids, Am J Clin Nutr. 2009; 90 (2) 288-297.

36. Filipiak K. J., Cybulska B., Dudek D., Grajek S., Gumprecht J., Imiela J., Jankowski P., Kasprzak J. D., Mamcarz A., Narkiewicz K., Rynkiewicz A., Siebert J., Tykarski A., Wożakowska-Kapłon B., Zdrojewski T., Aktualne problemy terapii dyslipidemii w Polsce Deklaracja Sopocka. Stanowisko ekspertów wsparte przez Sekcję Farmakoterapii Sercowo-Naczyniowej Polskiego Towarzystwa Kardiologicznego, For Med. Rodz. 2011; 1 (5) 1-5.

\section{Address for correspondence:}

Grażyna Mierzwa

Clinic of Vascular and Internal Diseases

Jan Biziel University Hospital No. 2

75 Ujejskiego Street

85-168 Bydgoszcz

Poland

tel./fax: +48523655105

e-mail: zpielgastro@cm.umk.pl

Received: 10.06.2016

Accepted for publication: 12.08.2016 